\title{
The Prevalence of E. coli From Diarrheic Calves and Their Antibiotic Sensitivity Test in Selected Dairy Farms of Debre Zeit, Ethiopia
}

\author{
Yeshiwas Tarekegn* and Fentahun W Molla \\ Department of Veterinary Medicine, Addis Ababa University, Ethiopia
}

Submission: August 09, 2017; Published: August 30, 2017

*Corresponding author: Yeshiwas Tarekegn, Department of Veterinary Medicine, Addis Ababa University, Ethiopia, Tel: +251-910-388-030; Email: bebehalf.31@gmail.com

\begin{abstract}
A cross-sectional study was conducted in 9 dairy farms in and around Debre Zeit from November 2015 to April 2016 with the major objective to estimate the prevalence of E. coli from diarrheic calves up to six months of age and assessment of risk factors associated with calf diarrhea as well as antimicrobial sensitivity testing. Fecal samples were collected directly from the rectum of diarrheic calves and isolation and identification of the bacterium were confirmed on the basis of their morphology, staining, cultural and biochemical tests. A total of 75 fecal samples were examined for the isolation of bacteria of which 53 (70.7\%) samples were positive for E. coli. Age was associated with the prevalence of E. coli $(X 2=26.094, P=0.00)$. Thus, age group less than two weeks $(\mathrm{OR}=1.6)$, had a higher odds for $\mathrm{E}$. coli infection as compared to those with age group in between 2-4 weeks, and above this weeks of age.
\end{abstract}

The prevalence of E. coli was found high in hand (bottle) feeding method colostrum and calves kept with calf pens having bedding material than those with direct suckling of colostrum and pens without bedding material respectively. However, there was no significant difference between the prevalence of E. coli and the types of farm ( $p>0.05)$. The antibiogram study revealed that most of the E. coli was highly susceptible to tetracycline, chloramphinicol, Sulfamethoxazole, streptomycin, and less susceptible to doxacilline, amoxicillin, nitrofurantoin, ceftazidime, and kanamycine. Furthermore, data regarding the management of the farms were generated through pretested questionnaire and direct observations. So that the recovery rate of E. coli was significantly higher in calves below two weeks of old. Therefore Based on those findings, calf diarrhea was found to high and could affect dairy production and it can be controlled through improved management practices as well as selected drugs to minimize the problem.

Keywords: E. coli; Calf diarrhea; Prevalence; Antimicrobial sensitivity; Risk factors

Abbreviations: CACC: Central Agricultural Census Commission [1]; CI: Confidence Interval; CLSFDA: Clinical Laboratory Standard Institute of Food and Drug Administration [2]; CSA: Central Statistical Authority; DF: Degree of Freedom; EMB: Eosin Methyl Blue; FAO: Food and Agriculture Organization; LF: Lactose Fermenter; MR: Methyl Red; NL: Non lactose Fermenter; NMSA: National Metrology Statistical Agency [3]; OF: Oxidation Fermentation; OIE: Office International des Epizooties [4]; OR: Odds Ratio; SD: Standard Deviation; SPSS: Statistical Package for Social Science; VP: Voges-Proskauer

\section{Introduction}

Livestock is an integral part of the agricultural production system in any country and plays an important role in national economy as well as in socio-economic development of millions of rural household. New born animals suffer fairly higher mortality than their adult counterparts and it is one of major reprisal over economy in livestock industry Radostits et al. [5]. Diseases have numerous negative impacts on productivity and fertility of herds i.e. losses due to mortality and morbidity, loss of weight, depressed growth, poor fertility performance, decrease physical power and the likes. Diarrhea in farm animals, especially in neonatal calves is one of the most challenging clinical signs

encountered by large animal veterinary practitioner CACC [1]. Diarrhea is a leading cause of economic losses to the cattle industry and major cause of calf mortality and morbidity during first few weeks of life Radostits et al. [5].

The incidence of diarrhea in calves under 30 days of age varies between $10 \%$ and $20 \%$. Calf diarrhea has an adverse effect on the calves' immediate health status, longevity in the herd and productivity performance and thus causes great economic losses. The economic losses occur not only from mortality but also from treatment costs and time spent on care as well as subsequent chronic ill, thrift and impaired growth 
performance Bazeley [6]. In order to increase the productivity per livestock unit without increasing livestock numbers and to devise preventive measures as well as to reduce losses during the initial months of life it is important to identify the etiological agents involved in calf diarrhea $[7,8]$.

A number of infectious (bacteria, viruses, parasites) and non-infectious factors cause diarrhea in neonatal calves. Previous studies show that the most important infectious agents are Rota virus, Corona virus, E. coli. Salmonella species and Cryptosporidium [9]. Numerous infectious pathogens capable of causing diarrhea among food animals have been associated with food born disease and Zoonosis in humans (enterohaemorrhagic E. coli, Salmonella, Rota virus and C. parvum) Trevejo et al. [10]. Among these organism Escherichia coli is the main cause for the calf diarrhea as white scour This bacterium is gram negative, rod shaped, flagellated, motile, Oxidize negative, facultative anaerobe and is classified under the family Enterobacteriaceae. It is genetically the most versatile bacteria and is the source of many plasmid and phage mediated genes. E. coli produces septicemia and diarrhea in a wide range of hosts including man, avian and animals $[11,12]$.

Diarrhea due to E. coli is one of the most common diseases of newborn calves (9-10 days of age) usually characterized by watery diarrhea, rapid onset and time course, and high mortality. In affected calves, diarrhea typically begins within 36-72 hours of birth, and affected calves die within 2-3 days. Some calves die several hours after appearing healthy and free of diarrhea Gyles [13]. The acute form is characterized by progressive dehydration and death, sometimes in as few as $12 \mathrm{hrs}$. In the sub acute form, diarrhea may persist for several days and characterized by a rise in temperature, weakness and lack of appetite which results in malnutrition and emaciation. In older animals there is a tendency or infection to localize itself in the joints of survivors. Lesions include enlarged, hemorrhagic spleens and the accumulation of synovial fluid in affected joints Awad [14].

Current treatment regimens for the treatment of neonatal calf diarrhea center on antimicrobial therapy and fluid therapy. Recently published studies described an increased incidence of resistance for different antimicrobials Orden et al. [15]. Discontinuation or incomplete course of treatment and continuous indiscriminate uses of antibacterial drugs against diarrheal infection of man and animal creates a potential health risk to animals and humans in terms of drug residues and the development of resistant bacterial strains. Although routine laboratory isolation and drug sensitivity testing are expensive and impractical, the periodical check of the pattern of the drug sensitivity of organisms is more significant. It is, therefore, important that sensitivity of different bacteria isolated from diarrheic calves needs to be studied from time to time in order to formulate appropriate therapeutic measures Kaura et al. [16].

Therefore, the objectives of this study were:

A. To determine the prevalence of $\mathrm{E}$. coli infection in diarrheic calves in and around Debre Zeit
B. To examine antimicrobial sensitivity of isolated bacteria

\section{Materials and Methods}

\section{Study area}

The study was conducted from November 2015 to May 2016 in dairy farms found in Debre Zeit and the surrounding areas which are located $45 \mathrm{~km}$ away from South East of Addis Ababa in east Shoa zone of Oromia region.

\section{Study population}

Three small sized, three medium-sized, and three large dairy farms were involved in the study period. Farms were classified as small ( $<5$ heads of dairy cow), medium sized (6-50 heads of dairy cow) and large ( $>50$ heads of dairy cow) based on previous works in the urban and peri-urban production system. The study included three breed dairy calves up to 6 month of age Lemma et al. [17]. Various information regarding the potential risk factors for the occurrence of diarrhea, including feed, management type, and herd size of each animal in the selected dairy farms, will be recorded before sample is collected.

\section{Study design and sampling methodology}

A cross sectional study was conducted in 9 dairy farms (small, medium sized and large) in and around Debre Zeit from November 2013 to April 2014 and a purposive sampling methods used to collect samples from calves that showed major clinical sign of diarrhea (elevated temperature, depression, dehydration, reduced suckling reflex, rough hair coat, loss of weight, weakness and soiling of hind quarter and tail with diarrheic feces Lemma et al. [17]. Approximately 32 grams of fecal material were collected directly from the rectum of diarrheic feces using disposable latex glove. Samples were placed into sterile universal ice box containing ice packs and transported to Addis Ababa University College of Veterinary Medicine and Agriculture microbiology laboratory for processing. Feces were stored at $4{ }^{\circ} \mathrm{C}$ until the time of processing. At the time of sampling the name of the farm, date of sampling, consistency of feces, age, breed, and tag number, feeding management practices as well as past history of diarrhea were recorded for each calf on a recording format.

\section{Questionnaire survey}

A pretested questionnaire was administered to dairy owners to assess the general calf husbandry practices. Generally the questionnaire includes all practices in the farm that performed about calf health care, hygiene, health problem, colostrums feeding time and duration as well as types of diarrhea that affect the growth of calves.

\section{Isolation and identification of E. coli from diarrheic calves}

Collection of sample: A total of 75 fecal samples were collected aseptically for isolation of E. coli pathogens from calf diarrhea and carried to the laboratory of the department of microbiology of Addis Ababa University, College of Veterinary Medicine and Agriculture. 


\section{Sample processing}

Bacteriological culturing and examination: All samples were cultured on blood agar and incubated aerobically at $37^{\circ} \mathrm{C}$ for 24-48hrs. After morphological examination, type of hemolytic, and gram staining characteristics pure colonies were further sub cultured on nutrient agar and MaCconkey agar for 24-48hrs at $37^{\circ} \mathrm{C}$. The presence of growth on MaCconkey agar was used as primary criteria to proceed for isolation and identification of E. coli. Furthermore the colony characteristics observed on MaCconkey agar was used to classify suspected bacteria isolated into two groups: lactose fermenter and non lactose fermenter. Suspected E. coli colonies were presumptively identified their lactose fermenting character (pink colonies), suspected E. coli further sub cultured Eosin methyl blue (EMB) agar medium to identify selectively E. coli. The characteristic colonies on EMB were identified based on green metallic sheen or blue-black to brown color. All isolated colonies were preserved on nutrient agar for further biochemical tests.

Primary identification of bacterial isolates: All isolates were checked for purity using gram staining technique and primary biochemical tests were conducted via, Oxidase test, Catalase test and Oxidation-fermentation tests. Bacterial isolates that showed a positive result on Catalase tests, negative result on oxidation test and fermentative up on O-F test were presumed to be members of Entero bacteria and were used for further studies.

Secondary identification of bacterial isolates: Isolated bacterial pathogens with specific cultural characteristics of E. coli were maintained on nutrient agar, and were subjected to biochemical tests such as Methyl red (MR), Vogues Proskauer (VP) test, Indole test, Citrate test, and Urease test Marchant \& Packer [18] and OIE [4].

\section{Antimicrobial susceptibility tests}

Antimicrobial susceptibility tests were performed using Kirby Bauer's disc diffusion method according to performance standards of CLSI Clinical and Laboratory Standards Institute [19]. The isolated colonies will be inoculated to nutrient and overnight at $37^{\circ} \mathrm{C}$. Suspension will be made in another similar broth and will be waited as long as the turbidity becomes equivalent to a 0.5 McFarland standard. Plates of Mueller Hinton (MH) agar will be seeded with about one millimeter of inoculums by sterilized swaps and antibiotic discs will be placed on the inoculated agar surface at about $2 \mathrm{~cm}$ apart. The plates will be incubated at $37^{\circ} \mathrm{C}$ overnight CLSI.

The diameter of the zones of inhibition will be measured by caliper or ruler. The measurements will be compared with zone size interpretative chart furnished by Clinical Laboratory and Standard Institute (CLSI) document M100 S23 (M02 A11) Disc diffusion supplemental tables and the Food and Drug Administration (FDA) recognized quality standards. Performance standards for antimicrobial susceptibility testing and the zones will be graded as susceptible, less susceptible and resistant CLSFDA [2]. The antibiotic discs included in the present study were, tetracycline $(30 \mu \mathrm{g})$, chloramphinicol $(30 \mu \mathrm{g})$, sulfamethoxazole $(25 \mu \mathrm{g})$, streptomycin $(10 \mu \mathrm{g})$, doxacilline $(30 \mu \mathrm{g})$, amoxicillin $(25 \mu \mathrm{g})$, nitrofurantoin $(300 \mu \mathrm{g})$, ceftazidime $10 \mu \mathrm{g})$, kanamycine $(30 \mu \mathrm{g})$, cefotaxime $(5 \mu \mathrm{g})$, vancomycine

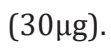

\section{Data analysis}

Data entry and validation were done using in Microsoft Excel (2007), and processed using SPSS software version 20 for appropriate statistical analysis. Descriptive statistics was done to determine the prevalence of E. coli from calf diarrhea among different age groups. Logistic regression and Chi-square (x2) was employed to analyze the association of the occurrence of E. coli with the potential risk factors like sex, age, breed, farm size, feeding management, hygein of the farm. The effect of risk factors on the occurrence of E. coli reactivity was summarized using univariate analysis with the models backward stepwise process was used to fit the final model. Effects were reported as statistically significant if p-values were taken as significant. (Values were considered statistically significant when the calculated P-value was less than 0.05).

\section{Results}

\section{Bacteriological examination of diarrheic calf feces}

Laboratory examination of 75 fecal samples from diarrheic calf that occurred during the study period was done to identify E. coli associated with calf diarrhea, and from this, 53 isolates (70.7\%) found to be positive for E .coli (Table 1).

Table 1: Frequency of $E$. coli in the feces examined by farm types.

\begin{tabular}{|c|c|c|c|}
\hline Farm Types & $\begin{array}{c}\text { Number } \\
\text { of Calves } \\
\text { Examined }\end{array}$ & $\begin{array}{c}\text { No and \% of } \\
\text { Calves +ve for } \\
\text { E. coli }\end{array}$ & OR(95\%CI) \\
\hline $\begin{array}{c}\text { Small sized } \\
\text { Farm }\end{array}$ & 16 & $10(13.4 \%)$ & Reference \\
\hline $\begin{array}{c}\text { Medium sized } \\
\text { Farm }\end{array}$ & 17 & $12(16.0 \%)$ & $1.56(0.45-27.8)$ \\
\hline $\begin{array}{c}\text { Large sized } \\
\text { Farm }\end{array}$ & 42 & $31(41.3 \%)$ & $1.97(0.22-17.5)$ \\
\hline Total & 75 & $53(70.7 \%)$ & \\
\hline $\mathrm{X}^{2}=11.511$ & $\mathrm{df}=8$ & $\mathrm{p}=0.17$ & \\
\hline
\end{tabular}

\section{Distribution of isolates in different scales of farms}

After laboratory examination of 75 fecal samples 10 cases was positive for E. coli from 16 samples obtained from small sized dairy farms, of 17 cases sampled from medium sized dairy farms 12 were positive for E. coli and from 42 diarrheic samples examined from large dairy farms, 31 samples were positive for E. coli (Table 2). 
Table 2: Types of diarrhea associated with E. coli.

\begin{tabular}{|c|c|c|c|}
\hline $\begin{array}{c}\text { Type of } \\
\text { Diarrhea }\end{array}$ & $\begin{array}{c}\text { Number } \\
\text { of Claves } \\
\text { Examined for } \\
\text { E. coli }\end{array}$ & $\begin{array}{c}\text { No and \% of } \\
\text { Claves +ve } \\
\text { Watery }\end{array}$ & OR(95\% CI)38 \\
\hline Watery & 38 & $32(42.7 \%)$ & Reference \\
\hline Bloody & 19 & $16(21.3 \%)$ & $0.22(0.025-0.85$ \\
\hline Mucoid & 8 & $2(2.7 \%)$ & $0.049(0.003-0.53)$ \\
\hline Mixed & 10 & $3(4 \%)$ & $0.009(0.00-0.27)$ \\
\hline Total & 75 & $53(70.7 \%)$ & \\
\hline $\mathrm{X}^{2}=27.071$ & $\mathrm{df}=3$ & $\mathrm{p}=0.000$ & \\
\hline
\end{tabular}

\section{Types of diarrhea associated with E. coli bacteria}

When the distribution E. coli among different types of calf diarrhea is considered, it was found that E. coli was recovered Table 3: Some description of the farms based on questionnaire result. at highest rate from watery diarrhea case followed by bloody diarrhea where as the isolation rates from other types of diarrhea were low and comparable. The difference in isolation rates of E. coli in different diarrheal types were statistically significant $(\mathrm{p}<0.05)$.

\section{Age associated with E. coli}

Furthermore, the distribution of E. coli among calves of different age groups was determined. In this regard, the isolation rates of E. coli decreased with increasing age of calves, the highest being in calves of $<2 \mathrm{wk}$ old. There was statistically significant difference between the age groups where E. coli was isolate. The difference in isolation rates of E. coli in different age groups were statistically significant $(\mathrm{p}<0.05)$ which is shown in Table 3.

\begin{tabular}{|c|c|c|c|c|}
\hline Factors & Category & Total Positive n (\%) & P-Value & OR (95\% CI) \\
\hline \multirow{4}{*}{ Age } & $<2 \mathrm{Wk}$ & $42(56 \%)$ & 0 & $1.6(1.025-2.75)$ \\
\hline & $2-4 \mathrm{Wk}$ & $8(10.7 \%$ & & $0.43(0.35-3.45)$ \\
\hline & $5-8 \mathrm{Wk}$ & $1(1.3 \%)$ & & $0.213(0.18-47.2)$ \\
\hline & $>8 \mathrm{Wk}$ & $2(2.67 \%)$ & & Reference \\
\hline \multirow{2}{*}{ Sex } & Male & $7(9.4 \%)$ & 0.617 & \\
\hline & Female & $46(61.3 \%)$ & & \\
\hline \multirow{4}{*}{ Type of Diarrhea } & Watery & $32(42.7 \%)$ & 0 & Reference \\
\hline & Bloody & $16(21.3 \%)$ & & $0.22(0.025-0.85)$ \\
\hline & Mixed & $3(4 \%)$ & & $0.09(0.00-0.27)$ \\
\hline & Mucoid & $2(2.7 \%)$ & & $0.04(0.003-0.53)$ \\
\hline Colostrums awareness & $\begin{array}{l}\text { Yes } \\
\text { No }\end{array}$ & $\begin{array}{c}75(100 \%) \\
0(0 \%)\end{array}$ & 0 & \\
\hline \multirow[t]{2}{*}{ Method of feeding } & Suckling & $17(22.7 \%)$ & 0.464 & \\
\hline & Hand feeding & $36(48 \%)$ & & \\
\hline \multirow[t]{3}{*}{ Time of first colostrums feeding } & $<6$ hour & $11(4.7 \%)$ & 0.66 & $0.3(0.33-276)$ \\
\hline & 6-12hour & $12(16 \%)$ & & $0.97(0.94-0.99)$ \\
\hline & $>12$ hour & $30(40 \%)$ & & Reference \\
\hline \multirow[t]{2}{*}{ Type of supplement } & Hay & $11(4.7 \%)$ & 0.53 & \\
\hline & Mixed & $42(56 \%)$ & 0801 & \\
\hline Bedding & Present & $37(49.3 \%)$ & 0.001 & \\
\hline \multirow[t]{2}{*}{ Treatment for sick } & $\begin{array}{c}\text { Absent } \\
\text { Antibiotic }\end{array}$ & $\begin{array}{c}16(21.4 \%) \\
36(8 \%)\end{array}$ & 0.72 & \\
\hline & Antihelmentic & $17(22.7 \%)$ & & \\
\hline Major health Problems & $\begin{array}{c}\text { Diarrhea } \\
\text { Pneumonia } \\
\text { Arthritis }\end{array}$ & $\begin{array}{c}45(60 \%) \\
25(33.3 \%) \\
5(6.7 \%)\end{array}$ & 0.5 & $\begin{array}{c}1.42(0.196-10.2) \\
\text { Reference } \\
0.77(0.26-2.25)\end{array}$ \\
\hline
\end{tabular}




\section{Questionnaire results}

In this study all the farms followed almost similar management system. Due to similarity of the farm management, no statistical comparisons were done for most of the farm factors. But some of the potential risk factors (age of calves, method of colostrum feeding, time of first colostrums feeding, presence or absence of bedding, feeding management, etc.) were included in the study. Generally, at this situation the farms kept 93.3\% crossbreed (Holstein x borana breeds or Holstein x local breeds), 5.3\% Borana breed and 1.4\% Zebu breed animals under intensive system of production.

Except one large dairy farm, all raises only heifer calves of which male calves were sold soon after birth. Most large and

Table 4: Age of calves associated with E. coli. medium sized farms had calving facility (separate calving pen). The knowledge of immunological importance of colostrums was present (All of the farms had the knowledge of the advantage of colostrums feeding over ordinary milk) however, a deliberate effort to fed calves with colostrums at the right time was practiced only in the large sized dairy Farms. $14.7 \%$ of the calves were positive for E. coli which feed colostrums before 6 hour old age, $16 \%$ calves were positive for E. coli which feed colostrums between 6 and 12 hour's old age, and $40 \%$ calves were positive for E. coli which feed colostrums after 12 hours of birth. $48 \%$ of the calves were positive for E. coli which got colostrums from direct suckling where as $22.7 \%$ calves were positive for E. coli which got colostrums from hand feeding or bottle feeding (Table 4).

\begin{tabular}{|c|c|c|c|}
\hline Age & Number of Claves Examined & No and \% of claves +ve for E. coli & OR(95\% CI) \\
\hline$<2 \mathrm{wk}$ & 46 & $42(56 \%)$ & $1.6(1.025-2.75)$ \\
\hline $2-4 \mathrm{wk}$ & 17 & $8(10.7 \%)$ & $0.43(0.35-3.45)$ \\
\hline $5-8 \mathrm{wk}$ & 1 & $1(1.3 \%)$ & $0.21(0.18-47.2)$ \\
\hline$>8 \mathrm{wk}$ & 11 & $2(2.67 \%)$ & Reference \\
\hline Total & 75 & $53(70.7 \%)$ & \\
\hline $\mathrm{X} 2=26.095$ & $\mathrm{df}=2$ & $\mathrm{p}=0.00$ & \\
\hline
\end{tabular}

Age to introduce to non-milk feed and weaning varied from farms to farms. The majority of large and medium sized farms wean their calves at one- two months of age, and three months of age in small sized dairy farm. $55.6 \%$ of calves were housed in separate pens with bedding of straw and $44.4 \%$ were housed ingroup pens without any bedding material and pens were cleaned twice a day. $49.3 \%$ and $21.4 \%$ of Calves were positive for E. coli in calves managed in separate pens with bedding and managed in-group pens without any bedding material respectively (Table 3).

In all large and medium sized dairy farms, there were professionals (veterinarian and/or animal health technician) either as fully employed or part time employed to deal with health aspects of the farms. The small sized dairy farms call private veterinary practitioners, when ever facing health problem of animals. $60 \%$ of the farm respondents indicate calf diarrhea as important problem. From the farm respondents there was variation in the occurrence of diarrhea among different age groups of calves where age groups $<2$ week old were greatly affected by diarrhea than other age groups (Table
3). The Laboratory work revealed the crucial role of E. coli in causing calf diarrhea. From personal observation and farmer's interview, inadequacy was found in some of calf management techniques.

From the above questionnaire results the associations between calves diarrhea and different age groups were calculated using chi square and logistic regression(odds ratio) at $95 \%$ confidence interval and the result indicates there is significant association between age group and occurrence of calf diarrhea ( $P$ value $<0.05)$.

\section{Sensitivity test result}

The results of antimicrobial susceptibility of the isolated E. coli are summarized in (Table 5). The antibiotic's sensitivity test of E. coli to 11 differentantibiotics such as cefotaxime, amoxicillin, ceftazidime, vancomycine, tetracycline, chloramphinicol, nitrofurantoin, sulphametoxazol, streptomycin, doxacilline and kanamycine were studied. A slight variation was noticed in the results of sensitivity of isolates against 11 different antibiotics used (Table 5). 
Table 5: Results of antimicrobial susceptibility test of the isolated E. coli.

\begin{tabular}{|c|c|c|c|c|c|}
\hline DRUG & Potency & Mean \pm SD & Sensitive & Less sensitive & Resistance \\
\hline Amoxicillin & $25 \mu \mathrm{g}$ & $12 \pm 0.4$ & & + & + \\
\hline Cefotaxime & $5 \mu \mathrm{g}$ & $13 \pm 1.5$ & & & $\mathrm{R}$ \\
\hline Ceftazidime & $10 \mu \mathrm{g}$ & $15 \pm 0.7$ & & & $\mathrm{R}$ \\
\hline Vancomycine & $30 \mu \mathrm{g}$ & $14 \pm 0.7$ & ++ & + \\
\hline Tetracycline & $30 \mu \mathrm{g}$ & $19.7 \pm 2.5$ & & & + \\
\hline Chloramphinicol & $30 \mu \mathrm{g}$ & $18.7 \pm 0.8$ & & & + \\
\hline Nitrofurantoin & $300 \mu \mathrm{g}$ & $15.7 \pm 1.0$ & ++ & & + \\
\hline Sulfamethoxazole & $25 \mu \mathrm{g}$ & $21 \pm 0.7$ & & & + \\
\hline Streptomycin & $10 \mu \mathrm{g}$ & $18 \pm 2.5$ & ++ & & + \\
\hline Doxacilline & $30 \mu \mathrm{g}$ & $21 \pm 1.6$ & & & + \\
\hline Kanamycine & $30 \mu \mathrm{g}$ & $16 \pm 1.0$ & & & + \\
\hline
\end{tabular}

Key: The above values are presented as Mean \pm SD of triplicate experiments where: $++=$ sensitive, $+=$ less sensitive, $\mathrm{R}=$ resistance, $\mathrm{SD}=$ standard deviation

\section{Discussion}

In the present study, an attempt was made to investigate the prevalence of E. coli in calves suffering from diarrhea, to determine the association of different risk factors and also to detect the antibiogram of those isolated E. coli in selected dairy farms located in and around Debre Zeit. This bacterium was also isolated from diarrheic calves by many other authors in different parts of the world [20-24]. Although, the present study focused on isolation of E. coli, the involvement of other microbial, parasitic or management factors as a cause of calf diarrhea could not be ruled out.

The detection of E. coli in this study $53(70.7 \%)$ out of 75 diarrheic samples is higher than the reports of Masud et al. [24] who out of 50 samples, 22 (44\%), Dereje [23] who out of 58 fecal samples, 25 (43.1\%) and lower than Paul et al. [22] who out of 100 fecal samples, 76 (76\%). This high and low prevalence may be due to the difference in climatic conditions, sample size, feeding managements, personal hygiene, and the type of age where sample collected as well as farm size.

E. coli is an intestinal comunsal bacteria commonly isolated from fecal samples. Therefore, isolation of E. coli from feces may not be directly associated with causation of diarrhea. Since methods required for identifying pathogenic strains of E. coli are not established yet at the laboratory, strain identification of E. coli isolates could not be carried out. However, the finding that E. coli were predominately recovered from diarrheic calves in the present study may be an indication for their importance in calves as causative agent for diarrhea in the study area.

In this study there was significant relation between types of diarrhea and E. coli which were in agreement with findings of Aggernesh [21] and Dereje [23]. When the prevalence of E. coli among different types of calf diarrhea is considered, it was recovered at highest rate from watery diarrhea. In the present findings diarrhea was highly associated with age of calves.
Accordingly, young calves (age group below 2 weeks) were at high risk of being affected with diarrhea. This could be due to a number of factors. From questionnaire survey, all the farms assessed administer colostrums to new born calves. However, the efficiency of colostrums intake and gut absorption may be affected by farm management practices.

The result can be associated with many factors, at younger age; delay in first colostrums feeding was associated with higher risk of being affected with diarrhea. The finding that delayed colostrums intake (latter than 6 hours of age) associated with high risk of being affected with diarrhea agrees with other reports. Olsson et al. [25] found that each hour of delay in colostrums ingestion in the first 12 hours of age increased the chance of a calf becoming ill by $10 \%$. Matte et al. [26] found that $61 \%$ of colostral immunoglobulin containing $80 \mathrm{mg} / \mathrm{ml}$ of 43 IgG is absorbed in six hours and decreases sharply thereafter. This indicates that the first six hours are the period in which maximum absorption of colostral immunoglobulin takes place [27]. Therefore, delays in administration could lead to lack of colostrum originated from originated maternal antibodies to protect calves from enteric pathogens.

This finding is compared well with the findings of Temesgen [28], Aggernesh [21] and Dereje [23] which they reported that calves aged between 0-30days were at great risk of diarrhea, particularly during the first week of life and risk decreases with age. This is well explained by Godden [29], Mellor \& Stafferd [30] who reported that the structure of the bovine placenta impedes easy acquision of immune globulins by unborn calves during pregnancy and therefore calves are borne without circulating protective antibodies. So they are more susceptible to different pathogens.

It is also indicated that the risk of failure of passive immunity transfer in bottle feeding is greater than in naturally suckled calves because of intake of inadequate colostrums volume and IgG and the mothering effect doesn't provide suitable gain to advocate leaving calves with the dam. But during bottle fed the colostrums might be contaminated with many environmental pathogens due to careless management systems. 
From the questionnaire survey, it was clear that calf diarrhea was among the major problems in the study area of the 9 farms which was the leading one $(60 \%)$ followed by pneumonia $(33.3 \%)$. The finding of calf diarrhea as predominant calf health problem was in agreement with the findings of Hussein [31], Lemma et al. [17], Demissie [21], Aggernesh [21] and Dereje [23] and reports of Olsson et al. [25], Debanth et al. [32] and Sivula et al. [33], who reported pneumonia as a second important disease complex that affects calf health. On the other hand, there are studies which found pneumonia as the leading calf health problem reported by Rao \& Nagarcenkar [34] and Shiferaw et al. [35].

Calf diarrhea as a leading health problem in the present finding suggests the significance of poor hygienic handling of feeding utensils and calf house observed during the study. On the other hand, the relatively lower cases of pneumonia encountered in this study might be due to small calf herd size per farms stocking density has strong correlation with environmental stress that exposes calves to respiratory problems; It was observed that a $50 \%$ decrease in stocking density was increasing the ventilation rate by 20 times thereby decreasing the risk of pneumonia [36].

Even though the sampling method and level of analysis do not allow statistical comparison of calf health problems between farm types, calf diarrhea was apparently higher in medium and large sized dairy farms than small dairy farms. The prevalence is also higher in calf pens having bedding material than without bedding material and in hand feeding source of colostrum than suckling as well as late feeders of colosturrm ( $>24$ hours) than early feeder (before 6 hours). This was in agreement with report of Temesgen [28] and Amoki [37].

The higher calf diarrhea in medium and large sized dairy farms can be due to the need for calf rearing facilities. The indiscriminate and continuous use of the same rearing facilities for different calves allows a buildup of infectious agents in the calf-rearing environment and hence increases the risk of calf disease.

The higher prevalence of E. coli in calf pens having bedding material can be due to hygienic conditions of the livestock's immediate environment on which bedding will cause for the accumulation wet and other manure. This was an important predisposing factor to stress and accumulation of bacteria. This agree with the reports of Smith et al. [38], given the natural grooming behavior of cattle and the potential for bacteria to become dispersed on dust particles it would seem logical that the hygienic conditions of the livestock's immediate environment, such as the floor of feedlot cattle pens or bedding provided for dairy cattle, would have significant impacts on bovine exposure to E. coli. In fact, reported that the prevalence of E. coli in cattle was greatest in pens that were muddy or wet. Dairy cattle housed in barns with flush-type manure removal systems were more likely to have E. coli than animals housed in barns where manure was removed by scraping Garber et al. [39].
During the study period small number of fecal samples was collected due to problems of getting diarrheic calves during the sampling period and this might have influenced the prevalence of pathogens detected. Therefore, thorough investigation of microbiology of calf diarrhea should be conducted on larger number of animals, near and under different agro climatic regions of the country to design appropriate control and preventive measures. All of the large and medium sized farms practiced immediate isolation of sick calves. In most of the farms, diarrheic calves did not receive appropriate treatments (the conduct only tentative diagnosis for the treatment of sick calves). This was also in agreement with the findings of Aggernesh [21] and Dereje [23].

The management of patients with infectious diseases must focus on patient safety, which includes minimizing the emergence and spread of resistant strains and deciding on the appropriate antimicrobial to administer. Moreover, the focal site(s) of infection should be identified to determine which bacteria are involved Wenzel et al. [40] and Evans [41].

The antibiogram study revealed that the isolated E. coli were highly sensitive to tetracycline, Sulfamethoxazole, chloramphinicol, streptomycin, doxacilline; less sensitive to amoxicillin, ceftazidime,

Nitrofurantoin, kanamycine and resistance to cefotaxime, vancomycine.

In this study the highly sensitivity of E. coli to chloramphinicol, Sulfamethoxazole and streptomycin agrees with the reports of Nazir [42] and Sherwood \& Snodgrass [43] who found that all the isolates were sensitivity to chloramphinicol and streptomycin. The highly sensitivity of E. coli to tetracycline and doxacilline agrees with the works of Joshi et al. [44], reported that high percentage of isolates were sensitive to tetracycline and doxacilline. These reports were also agreed with the study done in India by Sharma et al. [45] carried out antibiotic sensitivity test in E. coli strains from diarrheic calves and found that E. coli strains were most sensitive to streptomycin followed by doxycycline and trimethoprim.

The less sensitivity pattern of the isolate to amoxicillin and kanamycine in this study satisfy the result of panowar and Joon \& kaura [16] and these results were slightly dissimilar with the findings of Nazir [42], Ahmed et al. [46] and Genovese et al. [47] who stated that calf isolates were resistant to amoxicillin.

In this study, Cefotaxime was resistant for the isolated E. coli. These results are dissimilar to those from a study conducted in India in which it was found that lactose fermenter and non fermenter Enterobacteriaceae were susceptible to those antimicrobials Mehta et al. [48] and in Europe, Canada and the United States in the years 2000 and 2001, E. coli exhibited susceptibility to Cefotaxime. The variation in the sensitivity of antibiotics of the fecal isolates may be due to the outcome of choice and the indiscriminate use of antibiotic indifferent disease stage to various species of animals and technical factors 
influencing the size of the zone in the disc diffusion method like inoculum density, timing of disc application, temperature of incubation, incubation time, size of plate, depth of agar medium, and spacing of the antibiotic discs, potency of the antibiotic discs and composition of the medium.

\section{Conclusion}

In this study an attempt was made to determine the prevalence of E. coli associated with calf diarrhea, to know the risk factor, common health problems and to determine antibiogram sensitivity to isolates of E. coli from diarrheic calves from selected dairy farms in and around Debre Zeit. In the cases of this finding there appears to be an association between E. coli detected and age in the first two weeks of life as well as type of diarrhea. The prevalence of E. coli is high in calves kept in group pens with bedding material, in latter feeder of colostrums (above 24 hours) as well as in hand feeding source of colostrum than calves kept without bedding material, earlier feeder of colostrums ( $\leq 6$ hours of age) and suckling sources of colostrum respectively. The management of patients with infectious diseases must focus on patient safety, which includes minimizing the emergence and spread of resistant strains and deciding on the appropriate antimicrobial to administer. The findings of the present study indicate that the use of tetracycline, chloramphinicol, sulfamethoxazole, Streptomycin and doxacilline have the preference choice in clinical control of, E. coli causing calf diarrhea. Observational and questionnaire survey indicated that only aware of the advantage of colostrums feeding is not enough, but also times of colostrums administration to neonate calf are crucial for the ultimate success. The survey assessment also shows that, calf diarrhea appears one of the major constraints that reduce calf performance and that can be achieved through good management practices [49-51].

\section{Recommendations}

\section{Based on the conclusion we made on chapter five we forwarded the following recommendations}

A. Improved calf management practice that could reduce the high level of calf diarrhea like special emphasize to the time of colostrums feeding, the hygiene of calf house and isolation of sick calves should be implemented.

B. The use of tetracycline, chloramphinicol, sulfamethoxazole, streptomycin and Doxacilline has the preference choice in clinical control of E. coli causing diarrhea.

C. Since antibiotic susceptibility information is important in determining the guidelines for antibiotic therapy of infectious diseases, it is important that this information be collected on a regular basis.

D. Further detailed investigation on large number of animals should be carried out on microbial causes of calf diarrhea so as to design appropriate control and preventive measures.

\section{References}

1. CACC (2003) Statistical Reports on Livestock and Farm Implant, Part 4 Central Agricultural Census Commission, Addis Ababa, Ethiopia, pp. 45-46.

2. CLSFDA (2013) Interpretative chart furnished by Clinical Laboratory and Standard Institute (CLSI) and Food and Drug Administration (FDA) recognized quality standards. Document M100-S23 (M02-A11).

3. NMSA (2005) National meteorological service agency, rainfall and temperature data Addis Ababa, Ethiopia.

4. OIE (2000) Manuals of standards for diagnostics test and vaccines. OIE Guide-2.

5. Radostitis O, Blood D, Gay C (2000) Veterinary medicine. A text book of the disease of cattle sheep goats and horses ( $8^{\text {th }}$ edn), London, pp. 107-156.

6. Bazeley K (2003) Investigation of diarrhea in the neonatal calf. In Practice 25: 152-159.

7. Lorino T, Daudin J, Robin S (2005) Factors associated with time to neonatal diarrhea in French beef calves. Prev Vet Med 68(4): 91-102.

8. William and Zimmer (2013) Management of calves with clinical E. coli.

9. Dellafuente R, Garcia A, Gomez M (1998) Proportional morbidity rates of enteropathogens among diarrheic dairy calves in central Spain. Prev vet Med 36(2): 145-152.

10. Trevejo R, Barr M, Robinson R (2005) Important emerging bacterial zoometric infections affecting the immune compromised. Vet Res 36(3): 493-506.

11. Saylers A, Whitt D (2002) Diarrhoeagenic E. coli strains. Bacterial Pathogenesis Molecular approach, $\left(2^{\text {nd }} e d n\right)$, Amer Soc Microb 17: 407-420.

12. Hemashenpagam N, Kiruthiga T, Panneerselvam A (2009) Isolation of bacterial cause of calf diarrhea with special reference to $E$. coli. The Internet J Micro 7: 10-28.

13. Gyles C (1993) Pathogenesis of bacterial infections in animal's. $\left(2^{\text {nd }}\right.$ edn), Iowa state university, USA, pp. 164-187.

14. Awad M (2004) Virulence genes of verotoxin producing non E. coli strains isolated from healthy cattle in German. Germany vet J 91: 4755.

15. Orden J, Garcia S, De La fuente R (2000) Susceptibility of E. coli strains isolated from diarrheic dairy calves to 15 antimicrobials agents. J Ve Med 47: 329-335.

16. Kaura Y, Bhargava D, Pruth A, Prasad S (1988) isolation of multiple antibiotic resistant strains of $E$. coli from in turkey poultry. Indian J Poultry Sci 23: 9-13.

17. Lemma M, Kasha T, Azage T (2001) Clinically manifested major health problems of cross breed dairy breeds in urban and peri urban production systems in central highlands of Ethiopia. Trop Anim Health Prod 33(2): 85-93.

18. Merchant I, Packer R (1967) Veterinary bacteriology and virology. ( $7^{\text {th }}$ edn), USA, pp. 286-306.

19. Clinical and Laboratory Standards Institute (2006) Performance standard for antimicrobial disk susceptibility testing. $16^{\text {th }}$ Informational Supplement M100-S16.

20. Demissie D (2007) Microbial pathogens associated with calf diarrhea in dairy farms in and around Addis Ababa, Ethiopia. 
21. Aggernesh A (2010) Isolation and identification of Enterobacteria species from diarrheic calves in Debre Zeit dairy farms. Ethiopia.

22. Paul K, Khan M, Mahmud S (2010) Isolation and characterization of $E$. coli from buffalo calves in some selected areas of Bangladesh. Bangl J Vet Med 8: 23-26.

23. Dereje W (2012) Isolation and identification of Enterobacteria species from diarrheic calves in and around Addis Ababa, Ethiopia.

24. Masud M, Fakhruzzaman M, Nazir H (2012) Isolation of E. coli from apparently healthy and diarrheic calves in Bangladesh and their antibiogram. J Bang Soc Agric Sci Technol 9: 45-48.

25. Olsson S, Viring S, Emanuelsson V, Jacobson S (1993) Calf disease and mortality in Swedish dairy herds. Acta Vet Scand 34(3): 263-269.

26. Matte JJ, Girard CL, Seoane JR, Brisson GJ (1982) Absorption of colostral immunoglobulin $G$ in the newborn dairy calf. J Dairy Sci 65: 1765-1770.

27. Foley R, Bath D, Dickinson F, Tucker H (1985) Dairy Cattle problems, practices, problems and profits. ( $3^{\text {rd }} \mathrm{edn}$ ), lea and febiger, Philadelphia, USA, pp. 325- 338.

28. Temesgen W (2004) Calf morbidity and mortality in dairy farms in Debre Zeit and its Environs, Ethiopia.

29. Godden S (2007) colostrums management for dairy calves. In proceedings from the conference calf management Siolheim Hansen Steinkjer, Norway, Europe, pp. 20-22.

30. Mellor D, Stafford K (2004) Animal welfare implications of neonatal mortality and morbidity in farm animals. Vet J 168(2): 118-133.

31. Hussein A (1998) A study on calf mortality at Adamitulu livestock research center, proceeding of $5^{\text {th }}$ conference of Ethiopian Society of animal science, Ethiopia, pp. 15-17

32. Debanth N, Taimur M, Gburr E (1995) A retrospective study of calf losses on the central dairy cattle breeding station in Bangladesh. Prev vet Med 24(1): 43-53.

33. Sivula N, Ames T, Morsh W, Werdin R (1996) Descriptive epidemiology of morbidity in Minnesota dairy heifer calves. Prev Vet Med 27(4): 155171.

34. Rao MK, Nagarcenkar R (1980) Calf mortality in dairy cattle. Trop Anim Health Prod 12(3): 137-144

35. Shiferaw Y, Yohannes A, Gebrewold A, Gojjam Y (2002) Dairy husbandry and health management at Holeta, proceeding of the $16^{\text {th }}$ conference of the Ethiopian Veterinary Association, Addis Ababa, Ethiopia, pp. 103 119.

36. Blowey R (1990) The young calf in veterinary book for dairy farmers ( $2^{\text {nd }}$ edn), Farming press Ltd, UK, pp. 15-33.

This work is licensed under Creative

Commons Attribution 4.0 Licens

DOI:10.19080/AIBM.2017.06.555680
37. Amoki 0 (2001) Management of dairy calves in Holleta area, central highlands of Ethiopia. MSc Thesis, Ethiopia.

38. Smith D, Blackford S, Moxley J, Gray L, Hungerford T, et al. (2001) Ecological relationships between the prevalence of cattle shedding E. coli 0157: H7 and characteristics of the cattle or conditions of the feedlot pen. J Food Prot 64(12): 1899-1903.

39. Garber L, Wells L, Ferris K (1999) Factors associated with fecal shedding of verotoxin-producing Escherichia coli 0157 on dairy farms. J Food Prot 62(4): 307-312.

40. Wenzel R, Sahm D, Draghi D, Jones M (2003) In vitro susceptibilities of Gram-negative bacteria isolated from hospitalized patients in different countries to expanded-spectrum Cephalosporin. Antimicrob Agents Chemother 47(10): 3089-3098.

41. Evans M (2007) Antibiotic guidelines for the empirical treatment of sepsis in immune competent adult. Nottingham Antibiotic Guidelines Committee.

42. Nazir K (2007) Antibiogram pattern of E. coli isolates of calves feces and diarrhegenic stool of infants. J Bangla Soci Agri Sci Techno 4: 49152.

43. Sherwood D, Snodgrass D (1983) Prevalence of ETEC in calves in Scotland and northern England. Vet Res 113: 208-212.

44. Joshi B, Pociecha J, Yousif Y (1986) Drug sensitivity pattern of organisms isolated from calf Colibacillosis in Mosul (Iraq). Indian Vet J 63: 783-784.

45. Sharma D, Soni S, Kashyap S, Shringi B (2004) Antibiotic sensitivity pattern and transfer of plasmid coded characters of $E$. coli. Indian Vet J 81: 6-8.

46. Ahmad R, Amin W, Kazmi S (1986) Studied on the bacterial causes of calf mortality. Pak Vet J 6: 116-118.

47. Genovese K, Bischoff J, Mcreynolds R, Nisbet D (2006) Variation in the fecal shedding of Salmonella and E. coli in dairy cattle and examination of salmonella genotypes using pulsed-field gel electrophoresis. Lettappl Micro 38(5): 366-372.

48. Mehta M, Dutta P, Gupta V (2005) Antimicrobial susceptibility pattern of blood isolates from a teaching hospital in North India. Jpn J Infect Dis 58(3): 174-176.

49. Brhanu Y (2008) Microbiological studies of calf diarrhea and pneumonia in Debre Zeit, Ethiopia.

50. Stevanov C, Doikov I, Dimov R, Deenichin G, Delikostadinov G, et al. (2002) Clinical and bacteriological result from the administration of Cefepime (Maxipime) in patients with severe sepsis. Med Sci Monit 8(11): 197-102.

51. William and Zimmer (2013): Management of calves with clinical E. coli.

\section{Your next submission with Juniper Publishers} will reach you the below assets

- Quality Editorial service

- Swift Peer Review

- Reprints availability

- E-prints Service

- Manuscript Podcast for convenient understanding

- Global attainment for your research

- Manuscript accessibility in different formats

( Pdf, E-pub, Full Text, Audio)

- Unceasing customer service

Track the below URL for one-step submission https://juniperpublishers.com/online-submission.php 